\title{
Stock Market and Macroeconomic Policies: New Evidence from Pacific Basin Countries
}

\author{
Unro Lee \\ University of the Pacific, U.S.A.
}

\begin{abstract}
This article investigates whether the stock markets of the Pacific Basin countries of Hong Kong, Singapore, South Korea, and Taiwan are informationally efficient with respect to macroeconomic policies. Granger causality tests are utilized in the context of a Vector Error Correction Model to test the relationship between aggregate stock prices and monetary and fiscal policies. The findings indicate that the stock markets of all four countries are not efficient with respect to both macroeconomic policies. These findings are different from those of other articles focusing on major industrialized countries. Rejection of market efficiency may be attributed to the unique structure of financial markets in these countries (JEL G14).
\end{abstract}

Keywords: Pacific Basin countries, stock returns, macroeconomic policies, informational efficiency.

\section{Introduction}

One of the fundamental tenets of financial theory is that the value of common stocks is equal to the present value of expected future dividends. Because firms pay out dividends from earnings, which depend on real economic activity, stock prices should reflect current and expected future real economic activities. Since macroeconomic theory posits a significant relationship between macroeconomic policies both monetary and fiscal - and expected future economic activity, there should exist a strong intertemporal relationship between aggregate stock prices and macroeconomic policies. ${ }^{1}$

1. Baumol and Blinder (1994) provide an excellent description of the channel through which monetary and fiscal policies affect real economic activity. They indicate that

(Multinational Finance Journal, 1997, vol. 1, no. 4, pp. 273-289)

(C) by Multinational Finance Society, a nonprofit corporation. All rights reserved. DOI: $10.17578 / 1-4-2$ 
If the stock market is informationally efficient with respect to macroeconomic policies, then stock prices should quickly incorporate any changes in macroeconomic policies once this information becomes publicly available. ${ }^{2}$ Past information on these policies is of no use in explaining current fluctuations in stock prices in an efficient market since this information is already included in past prices. On the other hand, in an informationally inefficient market with respect to macroeconomic policies, past information on these policies is useful in explaining current movements in stock prices since there exists a lag in the adjustment of stock prices to new information.

Articles addressing the issue of stock market efficiency with respect to economic policies for the U.S. and other industrialized countries are inconclusive. Although there is overwhelming support for stock market efficiency with respect to monetary policy in these countries, many articles report that the stock markets of Belgium, Canada, France, and the U.S. are informationally inefficient with respect to fiscal policy, e.g., Rogalski and Vinso (1977), Kraft and Kraft (1977), Darrat (1987, 1990), Darrat and Brocato (1994), and Lee (1997).

Given the aforementioned disparities in empirical results for major industrialized countries, it would be interesting to determine whether Pacific Basin emerging stock markets fully capture relevant information on macroeconomic policies. Specifically, the objective of this article is to determine whether the stock markets of Hong Kong, Singapore, South Korea, and Taiwan are informationally efficient with respect to

contractionary monetary policy, for example, will lead to increases in interest rates via the central bank's ability to influence the amount of bank reserves. High interest rates tend to depress consumer spending, especially in durable goods and housing, and business investment, thereby contributing to a decline in aggregate demand. Since high interest rates also reflect high return on both physical and financial assets, this would attract capital flow from abroad, thereby inducing an appreciation of home currency value against foreign currency. The relative increase in home currency value would adversely affect exports and encourage imports, which would further dampen aggregate demand. Decline in aggregate demand would then translate to slowdown in the real economic activity. The channel through which fiscal policy affects real economic activity is similar. A sustained rise in budget deficit forces the government to issue bonds, which then drives up interest rates. The subsequent impact of higher interest rates on the economic activity is similar.

2. The term informational efficiency used in this article differs from the termeconomic efficiency used widely in the finance literature. It is possible that informational inefficiency may lead to economic efficiency if either the relationship between variables is weak or the trading costs are not zero. That is, even if lagged values of a variable can predict stock prices, the marginal benefit of acting on this information may not entirely offset the marginal trading cost such that excess return still cannot be generated. 
macroeconomic policies.

Hong Kong, Singapore, South Korea, and Taiwan, also known as the four little tigers, have enjoyed spectacular economic success since the early 1970s. Average annual real GNP growth for these countries was approximately $6.5 \%$ between 1980 and 1995, compared to 3\%, 3.5\%, and $1.8 \%$ for the U.S., Japan, and European Community (EC). Stock market capitalization for these four countries grew on average 59\% per annum during the 1980s. Aggregate stock prices increased by about $10 \%$ on an annual basis between 1980 and 1995. ${ }^{3}$ While these four Pacific Basin countries have been blessed with sustained healthy economic expansion during recent years, literature on the dynamic behavior of stock markets of these countries has been relatively scarce.

The article is organized as follows: Section II describes the data employed in this study. Section III presents a brief discussion on the empirical methodology. Section IV discusses the results. A summary of empirical findings and conclusions are presented in section V.

\section{Data}

Quarterly data for aggregate stock price, money supply, and budget deficit (or surplus) are obtained for Hong Kong, Singapore, South Korea, and Taiwan. ${ }^{4}$ The source of data for Hong Kong is the Hong Kong Monthly Digest of Statistics. The data for Singapore are from the Singapore Monthly Digest of Statistics. The data for South Korea are obtained from various issues of the Monthly Statistical Bulletin and Economic Statistics Yearbook, published by the Bank of Korea. The data for Taiwan are obtained from various issues of the Financial Statistics Monthly (Taiwan District) and Monthly Statistics of the Republic of China, both published by the central bank of China.

The stock indices used are the Hang Seng Index for Hong Kong, the Strait Times Industrial Index for Singapore, the Korea Composite Stock Price Index for South Korea, and the Taiwan Stock Exchange Index for Taiwan. The Hang Seng Index is a value-weighted index of 33 stocks. These stocks account for about $70 \%$ of the exchange's total market

3. These figures are obtained from various issues of the International Financial Statistics (IFS) and Kwok and Li (1993).

4. Budget deficit or surplus is used as the proxy for fiscal policy because it reflects the main thrust of fiscal policy, e.g., Darrat $(1988,1990)$ and Darrat and Brocato (1994). 
capitalization. The Strait Times Index includes 30 stocks. The Korea Composite Stock Price Index is a value-weighted index of all common stocks traded at the Korea Stock Exchange. The Taiwan Stock Exchange Index is a value-weighted index of all stocks traded at the Taiwan Stock Exchange; see Martin and Wood (1996).

The stock exchange of Hong Kong is the least regulated stock market in the world. The stock exchange of Singapore, however, is heavily regulated by the central bank of Singapore. The Korea Stock Exchange is still owned and managed by the Korean government. The Korean government has recently taken significant steps to deregulate Korean capital markets. The Taiwan Stock Exchange is the secondlargest stock market in the Pacific Basin. While both Hong Kong and Singapore are attracting foreign capital by relaxing interest rate regulations and abolishing exchange rate controls, South Korea and Taiwan impose restrictions on foreign ownership of their securities.

The periods investigated for this study are 1983:I to 1995:II for Hong Kong and Singapore, 1980:I to 1995:II for South Korea, and 1982:I to 1995:II for Taiwan. The incongruence in the sample period and the relatively short sample period chosen for this study are both due to the dearth of financial data for the Pacific Basin countries. ${ }^{5}$

\section{Cointegration Test Procedures}

The articles by Hall (1978) and Nelson and Plosser (1982) document non-stationary patterns in many macroeconomic variables. ${ }^{6}$ A nonstationary process requires differencing to induce stationarity. ${ }^{7}$ A variable that needs to be differenced $d$ times to reach stationarity is referred to as an $\mathrm{I}(d)$ or an integrated of order $d$ process. $\mathrm{I}(d)$ is also said to contain $d$ unit roots.

5. Kwok and Li (1993) and Kwok (1994), using quarterly data covering a relatively short time period, reject the proxy-effect hypothesis for the Pacific-Basin countries, a result consistent with those of other studies focusing on the United States and other industrialized countries with a longer sample period. Thus, the sample size does not appear to be an issue.

6. Hall (1978) shows that the aggregate consumption pattern follows a random walk process. Nelson and Plosser (1982) document that 14 other major macroeconomic variables exhibit non-stationary behavior over time.

7. The joint and conditional distributions of a stationary process are time-invariant. Consequently, the mean and variance of the process are stationary over time. 
A long-run equilibrium relationship between two or more nonstationary variables can be determined in a rigorous manner by applying a cointegration technique introduced by Granger (1983). According to Granger, in a vector of variables $X_{t}$, where all the variables are of the same order of integration, the components of $X_{t}$ are cointegrated only if the vector of error terms, $\varepsilon_{t}$, in the following equation is a stationary process:

$$
Z_{t}=\beta X_{t}+\varepsilon_{t}, \text { for } \beta \neq 0 .^{8}
$$

The Augmented Dickey-Fuller (ADF) test can be applied to determine whether each of the variables in $X_{t}$ is a non-stationary process; see Dickey and Fuller $(1979,1981)$. The ADF test for each of the variables in $X_{t}$, denoted by $Y_{t}$, is performed by estimating the regression equation

$$
\Delta Y_{t}=\alpha+\gamma t+\rho Y_{t-1}+\sum_{i=1}^{k} \beta_{i} \Delta Y_{t-i}+\xi_{t},
$$

where $Y_{t}$ is the variable under consideration. The order of $k$ is set large enough to ensure that the residual series, $\xi_{t}$, is a white-noise process. The null hypothesis that $Y_{t}$ contains a unit root is rejected when the estimated coefficient of the lagged variable, $\rho$, is statistically less than zero. The null hypothesis that $Y_{t}$ is $\mathrm{I}(d)$, where $d>1$, can be tested in the same manner after differencing $Y_{t}$ by $d$ times.

When all the variables in $X_{t}$ exhibit the same order of integration, Johansen's (1988) multivariate cointegration method can be used to uncover possible cointegrating relationships among the variables. Johansen's method involves the estimation of the following $k^{\text {th }}$ order vector autoregressive (VAR) equations:

$$
\begin{aligned}
& \Delta X_{t}=\Gamma_{1} \Delta X_{t-1}+\cdots+\Gamma_{k-1} \Delta X_{t-k+1}+\varepsilon_{1, t}, \\
& X_{t-k}=\Gamma_{1} \Delta X_{t-1}+\cdots+\Gamma_{k-1} \Delta X_{t-k+1}+\varepsilon_{2, t},
\end{aligned}
$$

where $X_{t}$ is a $n \times 1$ vector of variables that are integrated of same order,

8. Granger (1983) defines the components of the vector $X_{t}$ as being cointegrated of order $d$ and $b$ only if all components of $X_{t}$ are integrated of order $d$ and there exists a vector $\beta(\neq 0)$ such that $Z_{t}=\beta X_{t}$ is integrated of order $d-b>0$. 
$\varepsilon_{t}$ is an $n \times 1$ vector of residuals, and $\Gamma_{i}$ is a $n \times n$ coefficient matrix. The product moment matrices of the residuals, $\varepsilon_{1, t}$ and $\varepsilon_{2, t}$ are $S_{i j}=\Sigma \varepsilon_{1, t}$ $\varepsilon_{2, l} / T$, for $i, j=1$ and 2 , where $T$ is the sample size. The squares of the canonical correlation between $\varepsilon_{1, t}$ and $\varepsilon_{2, t}$ are ranked as $\varphi_{1}>\varphi_{2}>\ldots>\varphi_{n}$, where $\varphi_{i}, i=1,2, \ldots, n$, are also referred to as eigenvalues of $S_{21} S_{11}{ }^{-1} S_{12}$ with respect to $S_{22}$. Johansen introduced two likelihood ratio test statistics that can be used to test the null hypothesis of at most $r$ cointegrating relationships among the variables in $X_{t}$

$$
\begin{aligned}
& \lambda_{\text {trace }}(r)=-T \sum_{j=r+1}^{n} \ln \left(1-\varphi_{j}\right) \text { and } \\
& \lambda_{\text {max }}(r, r+1)=-T \ln \left(1-\varphi_{r+1}\right) .
\end{aligned}
$$

The first statistic, known as the $\lambda_{\text {trace }}$ statistic, is designed to test the null hypothesis of at most $r$ cointegrating relationships among the variables in $X_{t}$, against the alternative hypothesis of more than $r$ cointegrating relationships. The $\lambda_{\max }$ statistic is designed to test the null hypothesis of at most $r$ cointegrating relationships in $X_{t}$ against the alternative hypothesis of $r+1$ cointegrating relationships. The limiting distribution of both statistics is specified as an $(n-r)$-dimensional Brownian motion process. The quantiles of the distribution of these statistics are provided in table A3 of Johansen and Juselius (1990).

If there exists at least one cointegrating relationship among the variables in $X_{t}$, then the causal relationship among these variables can be determined by estimating the following Vector Error Correction Model (VECM):

$$
\Delta X_{t}=\alpha+\gamma \beta X_{t-1}+\sum_{j=1}^{k} \Gamma_{j} \Delta X_{t-j}+\varepsilon_{t}
$$

where $\alpha$ is a $n \times 1$ constant vector representing a linear trend, and $\gamma$ and $\beta$, both of which are of dimension $n \times r$, respectively denote the speed of adjustment and the cointegration vector, e.g., Johansen (1991).

Therefore, VECM relates changes in one variable to both the past equilibrium error and past changes in all the variables. That is, VECM simply assumes that a portion of the disequilibrium for a given period will be corrected in the subsequent period. According to the Granger Representation Theorem (Engle and Granger [1987]), the concept of 
cointegration and error correction are equivalent. As such, if all the variables in $X_{t}$ are found to be cointegrated, then their relationship can be adequately represented by a VECM.

The vector $X_{t}$ in this article consists of stock prices, money supply, and budget deficit. As such, $X_{t}=\left[S P_{t}, M_{t}, F_{t}\right]$ ', where $S P_{t}, M_{t}$, and $F_{t}$ represent stock prices, money supply, and budget deficit. In case of a single cointegrating relationship, equation 7 reduces to the following set of equations:

$$
\begin{aligned}
\Delta S P_{t}= & \alpha_{1}+\gamma_{1}\left(S P_{t-1}-\beta_{1} M_{t-1}-\beta_{2} F_{t-1}\right)+\sum_{i=1}^{k} \mu_{1, i} \Delta S P_{t-i} \\
& +\sum_{i=1}^{k} \theta_{1, i} \Delta M_{t-i}+\sum_{i=1}^{k} \lambda_{1, i} \Delta F_{t-i}+\varepsilon_{1, t}, \\
\Delta M_{t}= & \alpha_{2}+\gamma_{2}\left(S P_{t-1}-\beta_{1} M_{t-1}-\beta_{2} F_{t-1}\right)+\sum_{i=1}^{k} \mu_{2, i} \Delta S P_{t-i} \\
& +\sum_{i=1}^{k} \theta_{2, i} \Delta M_{t-i}+\sum_{i=1}^{k} \lambda_{2, i} \Delta F_{t-i}+\varepsilon_{2, t}, \text { and } \\
\Delta F_{t}=\alpha_{3} & +\gamma_{3}\left(S P_{t-1}-\beta_{1} M_{t-1}-\beta_{2} F_{t-1}\right)+\sum_{i=1}^{k} \mu_{3, i} \Delta S P_{t-i} \\
& +\sum_{i=1}^{k} \theta_{3, i} \Delta M_{t-i}+\sum_{i=1}^{k} \lambda_{3, i} \Delta F_{t-i}+\varepsilon_{3, t} .
\end{aligned}
$$

The null hypothesis of no causality from money supply to stock prices can be formulated as

$$
\mathrm{H}_{\mathrm{o}}: \gamma_{1}=0 \text { and } \theta_{1, \mathrm{i}}=0 \text {, for all } i
$$

If these estimated coefficients as a group are found to be statistically significant, then past values of money supply can explain variations in stock prices and the null hypothesis that money supply does not Granger cause stock prices can be rejected. On the other hand, if the estimated coefficients as a group are statistically insignificant, then past values of money supply are not useful in explaining fluctuations in stock prices and the null hypothesis should not be rejected. Stock market efficiency therefore implies that macroeconomic policies do not Granger cause stock prices. 
TABLE 1. Testing the Variables for Unit Roots Using the Augmented DickeyFuller Method

\begin{tabular}{|c|c|c|c|}
\hline A. Levels & $Y_{t}$ & $k^{*}$ & $t_{t}$ \\
\hline \multirow[t]{3}{*}{ Hong Kong } & SP & 1 & -1.81 \\
\hline & $\mathrm{M}$ & 3 & -2.05 \\
\hline & $\mathrm{F}$ & 4 & .50 \\
\hline \multirow[t]{3}{*}{ Singapore } & SP & 1 & -2.44 \\
\hline & $\mathrm{M}$ & 4 & -.62 \\
\hline & $\mathrm{F}$ & 3 & -1.31 \\
\hline \multirow[t]{3}{*}{ South Korea } & SP & 3 & -2.88 \\
\hline & $\mathrm{M}$ & 3 & 1.19 \\
\hline & $\mathrm{F}$ & 3 & -.82 \\
\hline \multirow[t]{3}{*}{ Taiwan } & SP & 1 & -2.12 \\
\hline & $\mathrm{M}$ & 1 & -1.15 \\
\hline & $\mathrm{F}$ & 3 & -1.52 \\
\hline B. First Differences & $\Delta Y_{t}$ & $k^{*}$ & $t_{t}$ \\
\hline \multirow[t]{3}{*}{ Hong Kong } & SP & 4 & $-5.01 * *$ \\
\hline & $\mathrm{M}$ & 2 & $-4.86 * *$ \\
\hline & $\mathrm{F}$ & 3 & $-4.73 * *$ \\
\hline \multirow[t]{3}{*}{ Singapore } & SP & 4 & $-5.00 * *$ \\
\hline & $\mathrm{M}$ & 3 & $-3.64 *$ \\
\hline & $\mathrm{F}$ & 2 & $-10.94 * *$ \\
\hline \multirow[t]{3}{*}{ South Korea } & SP & 2 & $-3.60 *$ \\
\hline & $\mathrm{M}$ & 4 & $-6.20 * *$ \\
\hline & $\mathrm{F}$ & 4 & $-8.08 * *$ \\
\hline \multirow[t]{3}{*}{ Taiwan } & SP & 1 & $-4.78 * *$ \\
\hline & $\mathrm{M}$ & 1 & $-4.86 * *$ \\
\hline & $\mathrm{F}$ & 2 & $-5.04 * *$ \\
\hline
\end{tabular}

Note: SP, M, and F respectively denote stock prices, money supply, and budget deficit. * and ** implies statistical significance at the 5 percent and 1 percent level. The critical values for $t_{t}$ statistic for $n=250$ at the $10 \%, 5 \%$, and $1 \%$ levels are respectively $-3.13,-3.43$, and -3.99 ; see Fuller (1976). $k^{*}$, the optimal lag-length, is determined by the Akaike Information Criterion (AIC).

\section{Empirical Results}

The ADF test is performed first to determine whether aggregate stock prices and both macroeconomic variables for the four Pacific Basin countries are non-stationary processes and integrated of the same order. The ADF test statistic, $t_{t}$, on $\rho$ in the equation 2 , is analyzed for all three variables. Since the results of the ADF test are found to be unduly sensitive to the choice of the lag length $k$ (see Thornton and Batten 
[1985]), the Akaike Information Criterion (AIC) is used to determine the optimal lag-structure specification of (2). AIC searches for the lag length $k$ that would minimize

$$
\operatorname{AIC}(k)=T \ln \left(\frac{S S R(k)}{T}\right)+2 p
$$

where $T$ is the number of observations, $\operatorname{SSR}(k)$ is the sum of squared residuals of the regression with $\mathrm{k}$ as the lag length, and $\mathrm{p}$ is the number of regressors equal to $k+1$. The appropriate order of the lag length for each variable in (2) is obtained by computing $\operatorname{AIC}(k)$ over the range of values for $k$ from 1 to 4 . The $k$ th lag that minimizes $\mathrm{AIC}, k^{*}$, is provided in table 1 for the three variables for all four countries.

Because the ADF statistic does not necessarily follow the usual student t-distribution under the null hypothesis of a unit root, the tabulated values provided in Fuller (1976) are used.

From panel A of table 1, we find that the null hypothesis of I(1) cannot be rejected at the 5\% significance level for stock prices, money supply, and budget deficits for all four countries.

Next, the null hypothesis of I(2) is tested for these three variables, the results of which are presented in panel $\mathrm{B}$ of table 1 . The ADF statistic indicates that the null hypothesis of $\mathrm{I}(2)$ can be rejected at the $1 \%$ significance level for all three variables for Hong Kong and Taiwan. The null hypothesis of $\mathrm{I}(2)$ can be rejected at the $1 \%$ significance level for both stock prices and budget deficit and at the 5\% level for money supply for Singapore. For South Korea, the null hypothesis is also rejected at the $1 \%$ significance level for both the money supply and budget deficit and at the 5\% level for stock prices. Therefore, stock prices, money supply, and budget deficit are found to have only one unit root for all four countries. That is, these three variables for all four Pacific Basin countries can be appropriately characterized as first-order, non-stationary processes.

Johansen's cointegration tests (with $n=3$ ), presented in table 2, show that the null hypothesis of no cointegrating relationship against the alternative hypothesis of one or more cointegrating relationships is rejected at the 5\% significance level for Singapore and Taiwan and at the $1 \%$ level for Hong Kong and South Korea. Also, the null hypothesis of a zero cointegrating relationship against the alternative hypothesis one cointegrating relationship is rejected at the $1 \%$ significance level for all four countries. These results indicate that at least one long-run 
TABLE 2. Multivariate Cointegration Tests Using Johansen's Method

\begin{tabular}{lccc}
\hline & $\mathrm{H}_{0}$ & $\lambda_{\text {trace }}$ & $\lambda_{\text {max }}$ \\
\cline { 2 - 4 } Hong Kong & $r=0$ & $40.23^{* *}$ & $27.52^{* *}$ \\
& $r=1$ & 12.71 & 10.55 \\
& $r=2$ & 2.16 & 2.16 \\
Singapore & $r=0$ & $39.94^{*}$ & $30.57^{* *}$ \\
& $r=1$ & 9.37 & 8.89 \\
South Korea & $r=2$ & .47 & .47 \\
& $r=0$ & $53.71^{* *}$ & $34.55^{* *}$ \\
Taiwan & $r=1$ & 19.16 & 13.46 \\
& $r=2$ & 5.69 & 5.69 \\
Critical Values at the 5\% & $r=0$ & $39.77^{*}$ & $29.80^{* *}$ \\
& $r=1$ & 9.98 & 9.66 \\
& $r=2$ & .31 & .31 \\
Crtitical Values at the 1\% & $r=0$ & 35.07 & 21.89 \\
& $r=1$ & 20.17 & 15.75 \\
& $r=0$ & 9.09 & 9.09 \\
& $r=1$ & 40.20 & 26.41 \\
& $r=2$ & 24.99 & 19.83 \\
& & 12.74 & 12.74 \\
\hline
\end{tabular}

Note: The $\lambda_{\text {trace }}$ statistic is designed to test the null hypothesis $\left(\mathrm{H}_{0}\right)$ of at most $\mathrm{r}$ cointegrating relationships among the variables against a general alternative $\left(\mathrm{H}_{1}\right)$ of more than $r$ cointegrating relationships. The $\lambda_{\max }$ statistic is designed to test the null hypothesis of at most $r$ cointegrating relationship among the variables against the alternative hypothesis of $r+1$ cointegrating relationships. The critical values for the above statistics are obtained from Table A3 of Johansen and Juselius (1990). * and ** denote the significance at the 5\% and $1 \%$ level, respectively.

equilibrium relationship among stock prices, money supply, and budget deficit can be detected for all four Pacific Basin countries.

Moreover, the null hypothesis of at most one cointegrating relationship against either the alternative hypothesis of two or more cointegrating relationships or the alternative hypothesis of two cointegrating relationships is not rejected for all four countries at both $5 \%$ and $1 \%$ levels. As such, we conclude that only one long-run equilibrium relationship among stock prices, money supply, and budget deficit exists for all four Pacific Basin countries.

Since it is determined that there is a cointegrating relationship among stock prices, money supply, and budget deficit, the causal relationship between stock prices and macroeconomic policies can be 
TABLE 3. Granger Causality Test Results From the Vector Error Correction Model (VECM)

A. Model

$$
\begin{aligned}
\Delta S P_{t}=\alpha_{1} & +\gamma_{1}\left(S P_{t-1}-\beta_{1} M_{t-1}-\beta_{2} F_{t-1}\right)+\sum_{i=1}^{4} \mu_{1, i} \Delta S P_{t-1} \\
& +\sum_{i=1}^{4} \theta_{1, i} \Delta M_{t-1}+\sum_{i=1}^{4} \lambda_{1, i} \Delta F_{t-1}+\varepsilon_{1, t}
\end{aligned}
$$

B. Null Hypothesis, $\mathrm{H}_{0}$ : Money supply does not cause stock prices

Hong Kong

Singapore

South Korea

Taiwan

C. Null Hypothesis, $\mathrm{H}_{0}$ : Deficit does not cause stock prices

Hong Kong

Singapore

South Korea

Taiwan
$\mathrm{F}(5,39)=4.20^{*}$

$\mathrm{F}(5,39)=2.92 *$

$\mathrm{F}(5,59)=2.48^{*}$

$\mathrm{F}(5,27)=3.30^{*}$

$\mathrm{F}(5,39)=2.91 *$

$\mathrm{F}(5,39)=2.34^{*}$

$\mathrm{F}(5,59)=2.26^{*}$

$\mathrm{F}(5,27)=2.90^{*}$

Note: $S P_{t}, M_{t}$ and $F_{t}$ denote stock prices, money supply, and budget deficit, respectively. Null hypotheses tested for money supply is $\mathrm{H}_{0}: \gamma_{1}=0$ and $\theta_{1 \mathrm{i}}=0$, for all $i$, and for deficit is $\mathrm{H}_{0}: \gamma_{1}=0$ and $\lambda_{1 \mathrm{i}}=0$, for all $i$. $*$ and $* *$ denote statistical significance at the 5 percent and 1 percent level.

investigated in the context of the VECM presented by (8a)-(8c). The length of the lag structures for these three equations is set as 4 for all four countries since quarterly data are used in this study. The following null hypotheses are then tested to determine the causal relationship among stock prices, money supply, and budget deficit

$$
\mathrm{H}_{0}: \gamma_{1}=0 \text { and } O_{1, i}=0 \text {, for all } i \text {, }
$$

or, money supply does not cause stock price, and

$$
\mathrm{H}_{0}: \gamma_{1}=0 \text { and } \lambda_{1, i}=0 \text {, for all } i \text {, }
$$

or budget deficit does not Granger cause stock prices.

Table 3 summarizes the results of the Granger causality tests. Both null hypotheses are rejected at the 5\% significance level for all four Pacific Basin countries. As such, both money supply and budget deficit 
Granger cause stock prices for all four countries. That is, past values of money supply and budget deficit can explain variations in stock prices in these four countries, suggesting that none of the four Pacific Basin stock markets is informationally efficient with respect to both monetary and fiscal policies. ${ }^{9}$

These results contradict Rogalski and Vinso (1977), Kraft and Kraft (1977), Darrat (1987, 1990), and Darrat and Brocato (1994), where the stock market is found to be informationally efficient with respect to monetary policy for major industrialized countries. At the same time, these results are consistent with Darrat $(1988,1990)$ and Darrat and Brocato (1994), where the stock markets of Belgium, Canada, France, and the U.S. are found to be informationally inefficient with respect to fiscal policy. Furthermore, the results for Taiwan are consistent with those of Fung and Lie (1990), who also find that the Taiwan stock market is inefficient with respect to money supply.

It is found that, even if there exists a long-run equilibrium relationship between macroeconomic policies and stock prices for these four Pacific Basin countries, stock prices do not necessarily adjust quickly and fully to the changes in either monetary or fiscal policy in the short run. Although it may be impossible to pinpoint exact causes of stock market inefficiency in these four countries with respect to both macroeconomic policies, a convincing argument can be made that the lack of stock market efficiency is partly due to the unique structure of these countries' financial markets.

Since the 1960s, South Korea and Taiwan have encouraged both commercial and specialized banks to extend low-interest loans to producers of export goods and intermediate suppliers to export industries in an attempt to stimulate economic growth. Consequently, unregulated financial markets, known as curb markets, emerged in the 1960s for households and corporations that were unable to secure cheap loans from commercial or specialized banks. Park (1994) documents that the size of the unregulated financial markets for South Korea grew from approximately $12 \%$ of the banking claims on the private sector in June 1980 to $38 \%$ of the banking claims in December 1989. The curb

9. Darrat (1990) suggests that other economic variables should be included in the causal model to remedy possible statistical biases that may result from omitting relevant variables. Fama (1981) claims that the consumer price index (CPI) and index of industrial production (IP) are significant determinants of stock prices. Granger causality tests were also performed using CPI and IP. The addition of the two variables in the VECM characterized by equations $8 \mathrm{a}-8 \mathrm{c}$ does not affect the results; results available from the author upon request. 
markets for Taiwan accounted for 30\% of total domestic assets by 1980 . Shea (1994) finds that the size of the Taiwanese curb markets peaked at $40 \%$ of total assets in 1986 before dropping to $24 \%$ in 1990 . As such, greater opportunities for households and firms to acquire credit from unregulated financial markets in both countries since the 1960s might have contributed to the diminished effectiveness of the monetary policy since these activities are outside the domain of the central bank's regulation. In addition, both the short-term and long-term interest rates in South Korea and Taiwan are heavily regulated by the government, which further mitigates the impact of monetary policy on the economy; see Park (1994) and Shea (1994).

Hong Kong and Singapore, unlike the other two countries, set their foreign exchange rates as the target for monetary policy in order to stimulate exports. Although Hong Kong adopted a floating exchange rate system between 1974 and 1983, it has since maintained a fixed exchange rate system by pegging the Hong Kong dollar (HK \$) to the U.S. dollar (U.S. \$) at the rate of HK \$7.8 per U.S. \$1.0, e.g., Lui (1991) and Scott (1997). Singapore, on the other hand, has pegged its currency (Singapore \$) to an undisclosed trade-weighted basket of currencies since September 1975. Unfortunately, both countries found that implementing effective monetary policy becomes difficult when government authorities peg their home currency to other major currencies. Consequently, Hong Kong has given up fine-tuning monetary policy altogether and has allowed it to be completely marketdriven. Likewise, Singapore has subordinated monetary policy to maintaining a stable foreign exchange rate in an effort to contain the inflation rate and preserve investors' confidence in its financial markets; see Peebles and Wilson (1996). Therefore, adoption of a fixed exchange rate system by both countries, Hong Kong in 1983 and Singapore in 1975, might have weakened the link between monetary policy and economic activity.

Likewise, Layman (1988) and Emery (1988) report that a discretionary fiscal policy has not been used extensively by South Korea and Taiwan as a vehicle to maintain economic stability and accelerate economic growth. In fact, both countries have strived for some time to maintain a balanced government budget. Moreno (1988) also finds that Hong Kong and Singapore have not utilized a discretionary fiscal policy to stabilize the economy.

Therefore stock market inefficiency in these four Pacific Basin 
countries exists in the short run partly because (i) monetary policy remains ineffective in South Korea and Taiwan due to the prevalence of unregulated financial markets and excessive government regulation of interest rates, (ii) monetary policy in Hong Kong and Singapore is not designed to directly influence domestic financial markets but to stabilize the exchange rate in order to stimulate exports, and (iii) fiscal policy is not frequently utilized by all four countries as a means to control economic activity. Investors of these four Pacific Basin countries, believing that macroeconomic policies are rendered either ineffective or insignificant as a means to stabilize economic activity, might have discounted the importance of relevant information subsumed in these policies in determining the fair value of common stocks.

\section{Conclusion}

The purpose of this article was to investigate whether monetary and fiscal policies affect movements in the stock markets of Hong Kong, Singapore, South Korea, and Taiwan. The Granger causality test method was used in the context of a Vector Error Correction Model (VECM) to test the relationship between aggregate stock prices and monetary and fiscal policies. It was found that the stock market was informationally inefficient with respect to macroeconomic policies for all four countries. That is, aggregate stock prices failed to fully capture all the relevant information subsumed in macroeconomic policies. ${ }^{10}$

These findings apparently contradict those of other studies that claim stock markets of industrialized countries are informationally efficient with respect to monetary policy. Such inconsistencies in the empirical results could have occurred partly due to the small sample size utilized in this study. Furthermore, the lack of stock market efficiency for these four Pacific Basin countries could be also attributed to the prevalence of unregulated financial markets (for South Korea and Taiwan) and passive monetary policy (for Singapore and Hong Kong).

10. It is true that informational inefficiency does not necessarily imply economic inefficiency since the magnitude of actual trading costs cannot be accurately gauged. However, Fama (1991) claims that testing for informational efficiency of a stock market has a definite advantage of obviating the "messy problem of deciding what the trading costs are" without sacrificing the robustness of statistical inferences about market efficiency. 


\section{References}

Akaike, H. 1974. A new look at statistical model identification. IEEE Transactions Automatic Control 19: 716-722.

Barnhart, S. W., and Darrat, A. F. 1989. Federal deficits and money growth in the United States. Journal of Banking and Finance 13: 137-149.

Baumol, W. J., and Blinder, A. S. 1994. Economics: Principles and Policy. New York: Dryden Press.

Darrat, A. F. 1987. Money and stock prices in West Germany and the United Kingdom: Is the stock market efficient? Quarterly Journal of Business and Economics 26: 20-35.

Darrat, A. F. 1988. On fiscal policy and the stock market. Journal of Money, Credit, and Banking 20: 353-363.

Darrat, A. F. 1990. Stock returns, money, and fiscal deficits. Journal of Financial and Quantitative Analysis 25: 387-398.

Darrat, A. F.2 and Brocato, J. 1994. Stock market efficiency and the federal budget deficit: Another anomaly. Financial Review 29: 49-75.

Dickey, D. A., and Fuller, W. A. 1979. Distribution of the estimators for autoregressive time series with a unit root. Journal of the American Statistical Association 74: 427-431.

Dickey, D. A., and Fuller, W. A. 1981. Likelihood ratio statistics for autoregressive time series with a unit root. Econometrica 49: 1057-1072.

Emery, R. F. 1988. Monetary policy in Taiwan, China. In H. Cheng (ed.), Monetary Policy in Pacific Basin Countries. Boston: Kluwer Academic Publishers.

Engle, R. F., and Granger, C. W. J. 1987. Cointegration and error correction: Representation, estimation and testing. Econometrica 55: 251-276.

Fama, E. F. 1981. Stock returns, real activity, inflation and money. American Economic Review 71: 545-565.

Fama, E. F. 1991. Efficient capital markets: II. Journal of Finance 46: 15751618.

Fuller, W. A. 1976. Introduction to Statistical Time Series. New York: Wiley.

Fung, H. G., and Lie, C. J. 1990. Stock market and economic activities: A causal analysis. In S. G. Rhee and R. P. Chang (eds), Pacific-Basin Capital Markets Research. Amsterdam, Netherlands: Elsevier Science Publishers.

Glick, R. 1988. Financial market changes and monetary policy in Pacific Basin countries. In H. Cheng (ed.), Monetary Policy in Pacific Basin Countries. Boston: Kluwer Academic Publishers.

Granger, C. W. J. 1983. Integrated variables and error-correcting models. Working paper. San Diego: University of California.

Hall, R. E. 1978. A stochastic life cycle model of aggregate consumption. Journal of Political Economy 86: 971-987.

Johansen, S. 1988. Statistical analysis of cointegrating factors. Journal of 
Economic Dynamics and Control 12: 231-254.

Johansen, S. 1991. Estimation and hypothesis testing of cointegrating vectors in Gaussian vector autoregressive models. Econometrica 59: 1551-1580.

Johansen, S., and Juselius K. 1990. Maximum likelihood estimation and inference on cointegration with applications to the demand for money. Oxford Bulletin of Economics and Statistics 52: 169-210.

Ko, K., and Lee S. 1991. A comparative analysis of the daily behavior of stock returns: Japan, the U.S. and the Asian NICs. Journal of Business Finance and Accounting 18: 219-234.

Kraft, J., and Kraft A. 1977. Determinants of common stock prices: A time series analysis. Journal of Finance 32: 417-425.

Kwok, R. 1994. Inter-relationship between stock returns and real economic variables: The experience of South Korea. Research in International Business and Finance 11: 217 - 226.

Kwok, R. and Li, K. 1993. The interrelationship between macroeconomic variables and stock prices in the newly industrialized economies of Asia. Research in International Business and Finance 10: 221-228.

Layman, T. 1988. Monetary policy and financial reform in Korea. In H. Cheng (ed.), Monetary Policy in Pacific Basin Countries. Boston: Kluwer Academic Publishers.

Lee, U. 1997. Stock market efficiency and money supply: New international evidence. International Journal of Finance 9: 635-649.

Lee, U. 1998. A test of the proxy-effect hypothesis: Evidence from Pacific Basin countries. Quarterly Journal of Business and Economics 37: 40-52.

Lui, Y. H. 1991. The foreign exchange market. In R. Y. K. Ho, R. H. Scott, and K. A. Wong (eds.), The Hong Kong Financial System. New York: Oxford University Press.

Martin, D., and Wood, B. 1996. Market microstructure and index returns: evidence from the Pacific rim. Journal of International Financial Markets, Institutions and Money 6: 45-58.

Moreno, R. 1988. Exchange rates and monetary policy in Singapore and Hong Kong. In H. Cheng (ed.), Monetary Policy in Pacific Basin Countries. Boston: Kluwer Academic Publishers.

Nelson, C. R., and Plosser, C. 1982. Trends and random walks in macroeconomic time series. Journal of Monetary Economics 10: 139-162.

Park, Y. C. 1994. Korea: Development and structural change of the financial system. In H. T. Patrick and Y. C. Park (eds), The Financial Development of Japan, Korea, and Taiwan. New York: Oxford University Press.

Peebles, G., and Wilson, P. 1996. The Singapore economy. Edward Elgar Publishing.

Rogalski, R., and Vinso, J. 1977. Stock returns, money supply and the direction of causality. Journal of Finance 32: 1017-1030.

Scott, R. H. 1997. Pegged exchange rate system in Macau and Hong Kong. 
Multinational Finance Journal 1(2): 153-168.

Shea, J. D. 1994. Taiwan: Development and structural change of the financial system. In H. T. Patrick and Y. C. Park (eds), The Financial Development of Japan, Korea, and Taiwan. New York: Oxford University Press.

Thornton, D. L., and Batten, D. S. 1985. Lag-length selection and tests of Granger causality between money and income. Journal of Money, Credit, and Banking 17: 164-178. 